DOI Number: 10.29064/ijma.514041

\title{
A CONCEPTUAL ANALYSIS OF CORPORATE GOVERNANCE AND ITS ENFORCEMENT
}

\section{Hatice Kübra KANDEMIR ${ }^{1}$}

\begin{abstract}
Reducing agency costs is the principal problem of corporate governance. Although the scope and stringency of the laws and rules on eliminating agency costs are expanding, there is still need for the understanding of the supervision and enforcement of these rules. Enforcement can take the forms of public and/or private. With dispersed and concentrated ownership patterns, the relevance of public and private enforcement mechanism may differ; due to the appearance of agency problems unlikely.

The purpose of this paper is to provide a conceptual analysis on corporate governance strategies involving the exercise of control rights, the appointment of independent directors, auditing, and disclosure. This paper will also include a guideline on the enforcement mechanism in Turkey and the ways in which they are used to control the agency problems; between owners and managers, controlling shareholders and non-controlling shareholders or creditors.
\end{abstract}

Keywords: Agency Problems, Control Rights, Independent Directors, Auditing, Disclosure, Regulation, Corporate Governance, Public Enforcement, Private Enforcement.

JEL Codes: G32, G34, G38, K22

\section{Introduction}

Although corporate governance has received worldwide recognition and acceptance, there is no single code suitable for different organizational structures and thus, every jurisdiction introduce their national corporate governance rules mostly founded on 'comply or explain' approach. Based on the principle of comply or explain, disclosure to the market regarding adherence to the code is required (OECD, 2017; 22). Governmental authorities, stock exchanges, and private sector or stakeholder groups share the responsibility of disclosing the adoption of such codes. In many jurisdictions corporate governance standards are also included in company and securities law. Therefore, the implementation and enforcement of these rules vary among countries. National public regulators in each jurisdiction have the authority to supervise and enforce the corporate governance practices of public companies. In Turkey the Capital Markets Board of Turkey; the SPK, is the main public regulator responsible for enforcing the corporate governance framework for listed companies.

The aim of this paper is to understand the role of the legal order in Turkey, in particular to the legal rules and regulations and corporate governance strategies established for eliminating agency costs. This paper also aims to provide a conceptual framework of the enforcement of corporate governance rules.

\footnotetext{
${ }^{1}$ Assist. Prof. Dr., Izmir Katip Celebi University, Faculty of Economics and Administrative Sciences, İzmir-Turkey. haticekubra.kandemir@ikc.edu.tr
} 


\section{Setting the Scene: Agency Theory and Corporate Governance}

In organizations where ownership and control is separated, owners delegate the duty of operating the company to a professional manager. In other words, those who manage the company and the company's owners are different. The role of managers is to direct the company in accordance to the specified objectives set by its shareholders.

The first type of agency problem, the so-called classic principal-agent problem, arises between principals (shareholders) and agents (managers) resulting from the opportunistic behavior of managers (Berle and Means, 1932). The incentives of managers to act opportunistically refer to self-interested behavior that may involve conducts such as misrepresentation for pursuing personal benefit or using company assets for personal use (Solomon, 2004).

When the ownership and control is separated, through a contract, the owner(s) delegate decision-making to a professional agent that is manager/director. The contract between the principal and the agent generally indicates that the agent shall not engage any activities that may harm the principal, and how the agent will compensate the principal in case of any harm occurs. This contractual relationship involves various costs, including transaction costs and monitoring costs (Jensen and Meckling, 1976; 306). With regard to transaction costs, first of all, there is the cost of calculating how to deal with all the possible scenarios that might occur throughout the contractual period. Second, there is the cost of consultation with others when planning to solve these odds. Third, in the case of a dispute, there is the cost of writing down the procedures in a way that a third person (e.g. a court) can interpret (Hart, 1995).

In the light of all these, the parties will not choose to write a detailed contract. Instead, the contract will not be fully developed and will be written in deficiency. In other words, there will be gaps and incomplete provisions in the contract - in some cases there will be only part of the course to follow, and even in some circumstances there will be no way to follow.

In any event, where the contract is incomplete, and there is agency problem to occur, corporate governance can be seen as a directive mechanism for situations not explained in the contract. For instance, corporate governance mechanism clarifies the distribution of rights to use the company's assets. The use of these rights in a single-person company will be directly owned by that person. Or, in the event of partnership, decisions will be taken by majority vote on who will access to assets. Companies may adopt these mechanisms within the scope of corporate governance.

In almost any contractual relationship where the agency relationship involved, the information asymmetry in favor of agents is likely to occur. It is observed that it is especially the small/minority shareholders who are subjected to asymmetric information. As a result, it is possible that the agents (managers) who have access to the information that the principals (owners) do not have, can gain unfair benefits. This conflict between controlling shareholders and non-controlling (minority) shareholders comprises the second type of agency problem. Here the primary concern is the possible exploitation of the rights of non-controlling shareholders by the majority in the firm. For instance, the agency problem in Turkish companies often occurs as controlling shareholders' incentives to exploit the rights of minority shareholders (Yurtoglu, 2000). The efforts of the owners to reach full information via monitoring on the agent whether 
the managers fulfill the terms of the contract is both costly and time consuming. This refers to the cost of monitoring.

The third agency problem involves the conflicts that may arise between the firm's owners and the other parties with whom the firm contracts, such as creditors, employees and customers. Here the challenge lies in assuring the firm, as agent, does not act opportunistically towards principals, such as expropriating creditors, or exploiting employees, or misleading customers (Kraakman et al., 2009).

In summary, the agency problem involves both the costs incurred by the contractual relationship between the owners and the managers, and the costs of the need to monitor and control the managers due to the risk of agent's incentives to behave opportunistically. In each of three type of agency problems, the fundamental issue is to eliminate the conflicts between the principal and the agent, which can take difference forms in each case. Corporate governance can play an important role in reducing agency costs and can be defined as the system of directing and controlling the company and making management accountable not only to shareholders but also to any other groups who have a stake in the company, including creditors (OECD, 2015). In fact, corporate governance is not only limited to governing of firms, but it can be adopted to similar organizations where an agency relationship involves. In relation to the governance of corporation, corporate governance deals with conflicts including those between shareholders and top managers, and controlling shareholders and minority shareholders or creditors.

This paper will continue with presenting the conceptual framework of corporate governance strategies in reducing agency costs. However, at first, it is necessary to introduce the legal strategies set for the protection of principals. These can be classified under two main categorizations: financial market and company law regulations.

\section{Legal Strategies: Financial Market and Company Law Regulations}

Corporate governance is primarily related to the managers on behalf of the company itself and its shareholders. Therefore, corporate governance, in general is a concern of company law. In addition, when a company issues its securities in the securities markets, investors and other third parties are also involved in this setting. The relationship between investors and public company is regulated by financial markets law.

\subsection{Financial Market Regulations}

Companies operating in financial markets are obliged to follow certain governance rules. For instance, listed companies in Turkey have to comply with the SPK rules and standards on transparency and disclosure. The ultimate objective of financial services regulation is to ensure that investor protection is secured and market confidence is maintained with reduced financial crime rates and other form of exploitation cases, such as insider trading (Baron and Besanko; 1984; Gerner-Beuerle, 2009). The motivation of financial markets regulation is usually justified to mitigate the aftermath of the crises and to reassure confidence in the market (Jackman, 2004). It is also beyond doubt that political intentions are involved in regulation e.g. to strengthen the political position and/or power (Baldwin and Cave, 2012; 41). 


\subsection{Company Law Regulations}

The company law regulations primarily aim to provide a company structure forming under a legal entity so that the company can fulfill some of the basic functions under this separate legal personality. Under the form of a company structure, first of all, the shares of the company can be transferred. This will ensure that the company's activities will continue without interruption even if the shareholders change. This also allows the shareholders to create a diversified investment portfolio. Secondly, a delegated management elected and appointed by the shareholders is formed under a board of directors (Kraakman et al., 2009). Hence, the corporate structure formed by company law regulations serve to facilitate a business environment that allows a more efficient operations of business firms. In order to fulfill the efficiency objective, the other main function of company law is to control conflict of interest among corporate participants, including the three type of 'agency problems' or 'principal-agent' problems; (i) shareholders and managers, (ii) controlling shareholders and non-controlling shareholders, and (iii) shareholders/directors and creditors (See also section 2 above). For example, company law regulations set mechanisms that impose constraints on agent's ability to exploit their principals, as well as on the ability of controlling shareholders to exploit the rights of minority shareholders. Similarly, in the case of agency problem between the company itself and the creditors, the rules of law protect creditors from opportunistic behavior of firms.

It may be concluded that regulatory strategies are used to constrain the agent's opportunistic behavior in order to protect principals; e.g. shareholders, minority shareholders, creditors, investors and alike. In this respect, under regulatory rules agents are prohibited specific behavior, such as making decisions or undertaking any transactions what would not in the best interest of the shareholders or the company itself. Regulatory rules depend on the ability of regulatory body in determination of agent's compliance with the rules (Kraakman et al., 2009).

In Turkey, the regulations related to the joint stock companies are included in the Turkish Commercial Code (hereinafter, TCC). Corporate governance principles are also embedded into the TCC with the amendments in 2011. In addition, companies whose shares are listed on the stock exchange are subject to the SPK regulations. The latest SPK Communique numbered II - 17.1 issued in 2014, involves the Corporate Governance Principles in which some of the rules are made obligatory to all joint stock companies, both listed and not-listed. Accordingly, companies whose shares are not listed on the stock exchange shall follow the rules on corporate governance if the number of shareholders exceeds 500 .

\section{Corporate Governance Strategies and Methods of Enforcement}

As the first part of this paper outlined, corporate governance can reduce agency problems and the costs associated to them. The availability of good quality regulations is important for good conduct of governance of corporations yet more important is their compliance and enforcement. Easterbrook and Fischel $(1984 ; 678)$ described it smoothly as "the world of inadequate enforcement, is similar to the world of no enforcement."

The supervision and enforcement of corporate governance rules can take place through public and private means (Jackson and Roe, 2009). Public enforcement includes criminal and civil law suits brought by public authorities. In addition to these, public 
enforcement also covers continuous monitoring of the disclosed information by the securities authorities. For instance, the SPK as a regulatory authority, has the ability to monitor compliance with the corporate governance rules and also is able to impose sanctions for any violations. In the form of private enforcement, a shareholder lawsuit may be taken to the court. Although private enforcement mostly embraces civil lawsuits brought by private parties, public actors may also be involved in these initiatives, particularly in cases where state owns major shares in a public company.

The next part will provide a conceptual analysis on the following corporate governance strategies in reducing agency costs; namely, (i) control rights, (ii) appointment of independent directors, (iii) auditing, and (iv) disclosure. In addition, enforcement methods for each of these strategies will be outlined.

\subsection{Control Rights and Enforcement}

Control rights (or managerial shareholder rights ${ }^{1}$ ) include the right to participate in the general shareholder meeting, right to obtain information and examination, right to request for a special audit, right to proceed, and right to vote to select the board members. These rights require shareholders to participate in decision-making process and to be included in identifying firm's strategies and objectives. As already explained, under the agency relationship, shareholders delegate decision-making power to the board of directors. Giving instructions regarding day-to-day management is the board of directors' duty. ${ }^{2}$ However, various measures may be taken against the possibility of loss or damage created on the part of shareholders. The ultimate objective of these measures is to strengthen the principals (primarily, the shareholders) against opportunistic behaviors of agents. The enforcement of these measures can take different forms.

\section{a. Shareholders' right to call a general assembly meeting}

The request of the shareholder to call a general assembly meeting from the board of directors is one of these measures. ${ }^{3}$ This course of action is particularly important to non-controlling shareholders because it introduces them an opportunity to determine the agenda of the meeting and make their voices heard by the board members. In case the board of directors rejects the request of the shareholders to call a meeting or do not respond within seven days, the shareholders may apply to the court (TCC, art. 412/1). The court may decide to call the general assembly to the meeting and may appoint a trustee to organize the agenda.

\section{b. The principle of equal treatment of the shareholders of the same type}

The principle of equality of corporate governance, stipulates that all shareholders is treated in a fair manner and that all shareholders in the same conditions are treated equally. This principle also refers to the equal treatment of the shareholders of the same type. Accordingly, shares in any type of shares must have the same rights and investors should be informed of the rights associated with the shares before purchasing them (OECD, 2015; 20).

Within this respect, TCC adopted the principle of the equal treatment of the shareholders who are in the same conditions. Accordingly, board decisions contrary to the principle of equal treatment shall be considered to be void (TCC, art. 391), ${ }^{4}$ in order to prevent arbitrary and subjective treatment of shareholders. Furthermore, shareholders may take action in court for annulment against the decisions of the general assembly that are contrary to the provisions of the law or articles of association and especially the rules of honesty (TCC, art. 445). 


\subsection{Appointment of Independent Directors and Its Enforcement}

In principle, the governing bodies of a company (managers and executives) are expected to serve in the best interest of the companies they manage. However, in practice, in companies (mainly in group of companies) the governing bodies are left in a situation where they have no choice but to follow the instructions of a dominant group, namely family members holding the majority of the capital. As a result, there is a risk of exploitation of small shareholders in companies in which managerial decision process take into consideration the interests of the dominant shareholders.

The appointment of independent members in the board of directors is suggested in order to protect small shareholders and set a monitoring system on the managerial decision process. In this respect, it is suggested that the majority of the board members must be compromised of non-executive members. Non-executive members may consist of persons who do not have any administrative duties in the company or they do not have a unit operating under their control and they are not involved in the company's ordinary and day-to-day business activities. Within the non-executive members, there must also be independent members capable of performing their duties in exclusive of any influence (SPK Corporate Governance Principles, art. 4.3.6, 4.3.7, and 4.3.8).

The functionality of the appointment of independent directors is questioned especially in firms with a controlling shareholder where in the controlling owner can both hire and fire board members (Berglöf and Claessens, 2006; 139). Hence, enforcement plays an essential role in ensuring that this rule serves its purpose.

In Turkey, the procedures and the requirements regarding the independent board members will be determined by the SPK (Turkish Capital Markets Law, art. 17). Here, the role of the regulatory authority is crucial especially because the SPK has involved in the appointment of independent directors through a screening process. The SPK conducts an examination regarding the independence criteria specified in Corporate Governance Principles, Article 4.3. $7^{5}$ and notifies the company of its negative opinions, if any. The person to whom the SPK declares negative opinion cannot be presented as independent member candidate in the general meeting.

\subsection{Auditing and Its Enforcement}

It is evident from the notorious case of Enron in the U.S., financial reports were used to mislead shareholders and investors (Coffee, 2002). The incentive of Enron's managers was to overstate the earnings to increase the share prices. So, Enron represents a typical first type of agency problem (see section 2 above); where in the managers do not act in the best interest of the company. The role of auditing here is to function as a monitoring mechanism over the opportunistic behaviors of managers (Watts and Zimmerman, 1983).

On the other hand, where the controlling shareholder have enough motivation and power to monitor management, incentives to commit fraud take different forms. Here, the controlling shareholder acts to extract private benefits through illegally transferring assets to other corporations (i.e. tunneling) as experienced in Imar Bank case in Turkey (Aktan et al., 2009). In such case, it is possible that the exploitation remains undiscovered for a long term, depending on the controlling shareholder's power. Also, the risk of exploitation is both on part of minority shareholders and creditors. The role of auditing with such ownership patterns is to provide assurance on the accuracy of the company's financial statements. In these companies, auditing serves an important 
governance function in such way that high-quality audits are used to convince outside investors and that the ability to exploit is limited thus the company could attract external finance (Jensen and Meckling, 1976; 323-325).

The role of auditing as a governance strategy is in fact comparable to the role of independent board members (see section 4.2 above). In both, the company relies on the judgement of a non-interested party on the approval of some certain transactions. In addition, auditors can be held liable, if found faulty, for participation in corporate fraud, or for failure to disclose fraudulent conduct (TCC, art. 554). In addition to civil liability, the SPK is authorized to issue a number of sanctions on audit firms, for example administrative and judicial fines, and cancellation of licenses for issuing false or misleading audit reports with intention or without taking reasonable care (Kandemir, 2015; 726-732).

\subsection{Disclosure and Its Enforcement}

The other corporate governance strategy in reducing agency costs is to provide a timely and accurate disclosure mechanism that ensures transparency regarding the corporation including the financial situation, performance, ownership, and governance of the company (OCED, 2015; 41).

\section{a. Disclosure of related-party-transactions}

With concentrated ownership structures, it is generally the case that controlling shareholders pursue to increase their personal benefits through related-partytransactions. ${ }^{6}$ This opportunism will likely to be successful where the controlling shareholders have the power to influence or, in most cases, to determine the outcome of a managerial decision. To overcome this kind of opportunistic behaviors, it is suggested that a non-interested party, who will not benefit from his/her decision, i.e. the independent board members, to approve the related-party transactions.

The law in Turkey requires the disclosure of related-party-transactions of public companies. Accordingly, independent directors' approval is necessary for all relatedparty transactions of public companies and if the independent members do not approve the transaction, this shall be publicly disclosed and shall be submitted to the general assembly for approval (SPK Corporate Governance Principles, art. 4.4.7). By disclosing the related party transactions, it is aimed to ensure that minority shareholders and other investors are informed in advance of potential conflicts of interests generated by such transactions. This disclosure may also discourage the controlling shareholder from tunneling the company assets to other sources (Schouten, 2009; 23) since the monitoring over the management will be more scrutinized.

However, in companies with a powerful shareholder, the functionality of disclosing related-party-transactions might be impaired. It is mainly because in these companies, shareholder pressure on the management may remain weak owing to the poor incentive to collect information and to monitor management (Sheifer and Vishny, 1997). Therefore, for ensuring that the board acts and decides in the best interest of the company and discouraging intensives for self-dealing, enforcement power of regulatory authorities plays an important role. With regards to disclosure obligations of public companies in Turkey, the screening on compliance is carried out through public supervision by the SPK. The SPK, if deemed necessary, may require the disclosure of any partnership and subsidiary relation and their related-part-transactions (SPK Communiqué, art. 9/9). 
SPK monitoring can be launched as a regular inspection routine or following an investor complaint. If an abusive related-party transaction is identified, the SPK issues a legal warning containing possible penalties to be charged if the losses are not compensated by the company. The SPK has also the authority to apply sanctions including the cancellation of licenses or issuing a criminal report to the Chief Public Prosecutor's Office (Cumhuriyet Başsavcılığı), as a last resort.

\section{b. Disclosure of information about large ownership}

Public disclosure of shareholders who have a significant share in a company, in other words, who reach or exceed a certain threshold, is important in terms of identifying potential conflicts of interests. It also helps to discover deceitful transactions that the company potentially to be engaged with the related parties. Therefore, the information about large ownerships in a company should be disclosed (OECD, 2015; 43) to perceive who control the company or who wants to take control. In this respect, corporate governance rules require the disclosure of the information of the ownership structure of public companies in their websites as means to show the names, shares, and proportions of the real person shareholders who hold more than 5\% of the shares (SPK Corporate Governance Principles, art. 2.2.3).

\section{Conclusion}

This paper has showed on the one hand, corporate strategies alongside with regulatory rules are used as tools for constraining agents for their opportunistic behaviors. These governance strategies, on the other hand, help to facilitate practices to increase the power of principals. This include the ability of the principals to intervene in the firm's management, e.g. through the exercise of control rights, the appointment of independent board members and auditors, and public disclosure of material information.

In a classic agency problem, corporate governance strategies may serve the purpose of controlling managers, which is the basis of the first agency problem. With concentrated ownership model, however, the problem is more on the risk of exploitation of minority shareholders and that is the second agency problem. For non-controlling shareholders, corporate governance strategies may be less effective, due to the comparatively adverse position in the firm. Thus, there is need for regulatory strategies; i.e. well-drafted financial market regulation, through for example investor protection rules.

This paper also concluded that corporate governance strategies largely rely upon public enforcement through specialized courts and monitoring activities of the public securities regulator, i.e. in Turkey, the SPK. Due to the concentrated ownership pattern, the corporate governance strategies alone are less effective. Public enforcement via the SPK screening and monitoring plays a fundamental role in the exercise of governance. However, this should not imply that private enforcement plays no such role. Private enforcement mainly relies on initiatives by principals (i.e. shareholders and creditors). For instance, it is possible to take action for shareholders to bring a liability claim against auditors or to fulfill an annulment action against general assembly decisions. Yet, if the coordination and communication among shareholders are weak, private enforcement activities may remain limited. Furthermore, litigation success depends on a certain level of development of the institutions (including courts, judges, and procedural law), and the legal environment. 


\section{REFERENCES}

Aktan, B., Masood, O., and Yilmaz, S. (2009). Financial shenanigans and the failure of ethics in banking: a review and synthesis of an unprecedented fraud. Banks and Banks Systems, 4(1), 30-36.

Baldwin R. and Cave, M. (2012). Understanding Regulation Theory, Strategy, and Practice. 2nd edn, Oxford University Press.

Baron, D. P. and Besanko, D. (1984). Regulation, Asymmetric Information, and Auditing. Rand Journal of Economics, 15(4), 447-470.

Berglöf, E. and Claessens, S. (2006). Enforcement and Good Corporate Governance in Developing Countries and Transition Economies. The World Bank Research Observer, 21(1), 123-150.

Berle, A. A. Jr. and Means, G. C. (1932). The Modern Corporation and Private Property. New York, MacMillan.

Coffee, J. C. Jr., (2002). Understanding Enron: "It's About the Gatekeepers, Stupid". The Business Lawyer, 57, 1403-1420.

Coffee, J. C. Jr., (2006). Gatekeepers: The Professions and Corporate Governance. Oxford University Press.

Easterbrook, F. H. and Fischel, D. R. (1984). Mandatory Disclosure and the Protection of Investors. Virginia Law Review, 70(4), 669-715.

Eminoğlu, C. (2014). Türk Ticaret Kanunu'nda Kurumsal Yönetim (Corporate Governance). 12 Levha.

Gerner-Beuerle, C. (2009). The Market for Securities and Its Regulation through Gatekeepers. Temple International and Comparative Law Journal, 23, 317-377.

Hart, O. (1995). Corporate Governance: Some Theory and Implications. The Economic Journal, 105(430), 678-689.

Jackman, D. (2004). Does Regulation Make It Worse?. Journal of Financial Regulation and Compliance, 12(2), 106-110.

Jackson, H. E. and Roe, M. J. (2009). Public and Private Enforcement of Securities Laws: Resource-Based Evidence. Journal of Financial Economics, 93, 207-238.

Jensen, M. C. and Meckling, W. H. (1976). Theory of the Firm: Managerial Behavior, Agency Costs and Ownership Structure. Journal of Financial Economics, 3(4), 305-360.

Kandemir, H. K. (2015). External Auditing in Turkey: A Critical and Comparative Analysis of the New Law. European Business Organization Law Review, 16, 711-734.

Kraakman, R., Armour, J., Davies, P., Enriques, L., Hansmann, H. B., Hertig, G., Hopt, K. J., Kanda, H., and Rock, E. B. (2009). The Anatomy of Corporate Law. 2nd edn, Oxford University Press.

OECD (2015), G20/OECD Principles of Corporate Governance, September 2015.

OECD (2017), OECD Corporate Governance Factbook 2017.

Schouten, M. C. (2009). The Case for Mandatory Ownership Disclosure. MPRA Paper No. 14880. Available online at http://mpra.ub.uni-muenchen.de/14880/. 
Shleifer, A. and Vishny, R. W. (1997). A Survey of Corporate Governance. The Journal of Finance, 52(2), 737-783.

Solomon, J. (2004). Corporate Governance and Accountability, 3rd edn, John Wiley \& Sons.

SPK (2014). Communiqué on Corporate Governance Principles II-17.1, Official Gazette No: 3/1/2014.

Turkish Capital Markets Law, No. 6362, Official Gazette No: 30/12/2012.

Turkish Commercial Code (TCC), No. 6102, Official Gazette No: 14/2/2011.

Watts, R. L. and Zimmerman, J. L. (1983). Agency Problems, Auditing, and the Theory of the Firm: Some Evidence. The Journal of Law and Economics, 26(3), 613-633.

Yurtoglu, B. B. (2000). Ownership, Control and Performance of Turkish Listed Firms. Empirica, 27, 193-222.

\section{NOTES}

\footnotetext{
${ }^{1}$ Other rights arising from ownership are referred to 'monetary shareholder rights' include right to receive dividend, right to participate in the share of liquidation, right to buy bonus shares and preemptive right.

${ }^{2}$ The main duty of the board of directors is to manage and represent the company (TCC, art. $365)$.

${ }^{3}$ In private companies, shareholders holding at least $1 / 10$ of the capital and shareholders representing $1 / 20$ of the capital in public companies may ask the board of directors to convene a general meeting. (TCC, art. 411/1).

${ }^{4}$ Even though the law explicitly states that the board decisions will be void in case of the violation of the principle of equal treatment, it is accepted also decisions of the general assembly conforms to this rule (Eminoğlu, 2014; 127).

${ }^{5}$ These criteria involves, but not conclusively, the requirements of such as having the necessary education, information and experience so that the independent director to contribute positively to the company's activities and to be able to remain neutral in the conflicts of interests that may arise between the company and its shareholders. See SPK Corporate Governance Principles, art. 4.3.7.

${ }^{6}$ Related-parties include (i) entities that control or are under joint control over the company, (ii) significant shareholders that have and impact on the company, and (iii) members of the family and the key management personnel of the company or its parent company. See Turkish Accounting Standards (TMS) 24, in accordance with International Accounting Standards (IAS).
} 